\title{
HUBUNGAN ANTARA POLA ASUH ORANG TUA DENGAN MINAT BACA ANAK
}

\author{
Savira Arumdini ${ }^{1}$, Yunus Winoto ${ }^{2}$, Rully Khairul Anwar ${ }^{3}$ \\ ${ }^{1}$ IPC Logistic PT Multi Terminal Indonesia, \\ ${ }^{2,3}$ Program Studi Ilmu Perpustakaan Universitas Padjadjaran \\ 1 savirard@gmail.com, ${ }^{2}$ yunuswinoto@gmail.com, ${ }^{3}$ rkha.fikom@gmail.com
}

ABSTRACT - Relationship between parenting style and children's reading interest is the title of this research, subbed with "Explanatory survey at AlMa'soem Junior High School, Sumedang". This research is aimed to know is there any relationship between parenting style and children's reading interest. Method used is quantitative with explanatory survey, that is directed to pay attention on the cases in certain situations and conditions present in the community, and its explanation by conducting a survey analysis that is designed to answer the question in the form why. Data collection techniques used questionnaires, observation, interview and litterature study. The sampling techniques used are simple random sampling. Data collection using questionnaires distributed to 89 respondents who are Al-Ma'soem junior high school students. The analysis technique used in this research is descriptive data analysis and inferential analysis. For inferential analysis used rank Spearman correlation test. Recommendation from this Result of this study showed a correlations between parenting style and children's reading interest. Recommendation suggested from this research in terms of the children's reading interest, parents apply control and warmth equally high is the most effective way to improve children's reading interest.

Keywords: Parenting, parents, reading interest, explanatory survey.

ABSTRAK - Penelitian ini berjudul hubungan antara pola asuh orang tua dengan minat baca anak dengan sub judul survey eksplanasi di Sekolah Menengah Pertama Al-Ma'soem, Sumedang. Tujuan dari penelitian ini yaitu untuk mengetahui adakah hubungan antara pola asuh orang tua dengan minat baca anak. Penelitian ini menggunakan metode kuantitatif dengan format survey eksplanasi, yaitu penelitian yang diarahkan untuk memperhatikan mengenai kasus-kasus yang terjadi pada situasi dan kondisi tertentu masa kini di dalam masyarakat, dan penjelasannya dengan melakukan survey analisis yang di rancang untuk menjawab pertanyaan yang berbentuk mengapa. Teknik pengumpulan data dengan menggunakan kuesioner, observasi, wawancara, dan studi kepustakaan. Teknik pengambilan sampel dalam penelitian ini dilakukan dengan cara sampel acak sederhana. Proses pengumpulan data menggunakan kuesioner yang disebarkan kepada 89 responden yang merupakan murid SMP Al-Ma'soem. Teknik analisis yang digunakan adalah teknik analisis data deskriptif dan analisis inferensial. Untuk analisis inferensial digunakan uji korelasi rank Spearman. Hasil dari penelitian ini menunjukan adanya hubungan antara pola asuh orang tua dengan minat baca anak. Saran dari penelitian ini dilihat dari segi minat baca anak yaitu pola pengasuhan orang tua yang sangat efektif untuk meningkatkan minat baca anak adalah pola pengasuhan yang menerapkan dimensi kontrol dan kehangatan sama-sama tinggi.

Kata kunci: Pola asuh, orang tua, minat baca, survey ekplanasi.

\section{PENDAHULUAN}

Bukan menjadi sebuah rahasia lagi bahwa buku adalah gudangnya ilmu. Bahkan, meski saat ini banyak informasi yang beredar di dunia maya, hampir bisa dipastikan semua informasi di sana berasal atau minimal berawal dari sebuah buku.

Sebab buku adalah catatan sejarah dan kisah yang ditulis dengan banyak referensi. Silahkan masukan kata kunci "membaca untuk kesuksesan" pada search engine dan anda akan mendapatkan 500 lebih entri yang keluar mengenai topik tersebut dan juga bukan rahasia lagi bahwa membaca merupakan salah satu kunci kesuksesan, tidak ada seorangpun di dunia ini 
yang sukses tanpa membaca. Membaca adalah salah satu cara untuk membuka cakrawala dunia. Membaca buku juga merupakan kegiatan utama dalam pendidikan. Lewat membaca, kita memperoleh pengetahuan baru, informasi, hiburan dan lain sebagainya.

Membaca sangatlah penting untuk menambah wawasan dan pengetahuan dalam menilai maupun dalam menghadapi berbagai tantangan di masa depan, dengan membaca seseorang akan memiliki rasa kebahasaan yang tinggi, yang dengan rasa kebahasaannya itu ia akan mampu bedan memahami gagasan rumit secara lebih baik. Dengan pengetahuan yang diper- oleh melalui membaca, seseorang akan memiliki wawasan yang lebih luas, sehingga ia dapat memberikan berbagai perspektif bagi orang lain maupun dirinya sendiri.

Tumbuhnya minat dan kebiasaan membaca khususnya di kalangan anak- anak tidak bisa datang dengan sendirinya dari luar, minat baca harus dipupuk dari dalam keluarga sendiri karena itu ada baiknya orang tua mulai menumbuhkan kebiasaan membaca dari semenjak dini agar anak terbiasa untuk menyukai kegiatan membaca. Peran dari berbagai pihak diantara peran orang tua, guru sekolah, dan pihak-pihak terkait lainnya juga sangat memperngaruhi kecintaan anak akan kegiatan membaca. Anak yang gemar membaca tidak datang dari anak itu sendiri akan tetapi anak yang gemar membaca biasanya mempunyai orang tua dan guru yang mampu membimbing untuk membaca.

Kebiasaan membaca ini terbentuk pada diri seseorang karena dipengaruhi oleh faktor eksternal yang meliputi faktor sosial dan faktor lingkungan. Faktor sosial meliputi pergaulan sesama teman sewaktu di sekolah dan tempat les maupun di luar keduanya, sedangkan faktor sosial terbesar bagi perkembangan minat baca anak datang dari keluarga, yaitu melalui pola asuh orang tua, hubungan antara orang tua dan anak sangat mempengaruhi perkembangan sosial anak. Adapun faktor lingkungan yaitu faktor keadaan lingkungan di mana seseorang berada, misalnya ada tidaknya tempat membaca yang memadai, dana untuk pengadaan bahan bacaan, dan lain-lain.

Namun sayangnya, kebiasaan membaca bagi anak masih menempati prioritas terendah dibandingkan dengan kegiatan anak yang lainnya, seperti bermain di luar dengan teman-temannya, menonton TV, dan bermain video games. Karena itu diperlukan peranan orang tua yang tepat guna menumbuhkan minat baca anak. Peran orang tua seperti membacakan cerita kepada anak sebelum anak tidur, mengajak anak ke perpustakaan, memberikan hadiah buku kepada anak, mengajak anak ke toko buku/ pameran buku, merupakan beberapa bentuk peranan yang dapat dilakukan oleh orang tua dalam menumbuhkan kebiasaan membaca anak.

Kebiasaan masyarakat Indonesia dalam membaca dan menulis masih terbilang sangat rendah. Tak usah jauh menelisik pada masyarakat Eropa seperti Inggris, Prancis, Jerman, atau bahkan di Amerika, di kawasan Asia Tenggara (ASEAN) saja, Indonesia menempati urutan ketiga terbawah di kawasan ASEAN. Merujuk pada hasil survei United Nations Educational, 
Scientific and Cultural Organization (UNESCO) pada 2011, indeks tingkat membaca masyarakat Indonesia hanya 0,001 persen. Artinya, hanya ada satu orang dari 1000 penduduk yang masih 'mau' membaca buku secara serius (tinggi). Sedangkan rata-rata indeks tingkat membaca di negara-negara maju berkisar antara 0,45 hingga 0,62. Kondisi ini menempatkan Indonesia pada posisi 124 dari 187 negara dalam penilaian Indeks Pembangunan Manusia (IPM) (El-Fikri, 2015 ).

Kondisi ini tentu saja sangat memprihatinkan. Budaya membaca di Indonesia sampai saat ini masih sulit diterapkan, karena itu dalam membangun minat baca, peran dari orangtua sangat penting. Orangtua harus menjadi contoh dan kontrol yang baik bagi anak. Pola asuh orang tua dilakukan sejak anak lahir sampai dia menjadi dewasa. Pola asuh ini akan terus dirasakan dan akan menjadi bagian dari pengalaman seseorang. Perlakuan berda sarkan pola asuh ini merupakan suatu hal yang selalu dialami sehingga akan membentuk suatu pandangan tersendiri dari anak tentang pola asuh tersebut. Karena anak mengalami sendiri pola asuh orang tua yang diterapkan, maka anak dianggap mampu mengungkapkan pandangannya terhadap apa yang dirasakan mengenai pola asuh orang tua selama ini.

Orang tua merupakan bagian dari keluarga dan keluarga adalah lingkungan yang pertama kali ditemui oleh seorang anak. Dalam keluarga, anak belajar bertingkah laku, tumbuh dan berkembang. Pola asuh yang diterima seorang anak bersifat subjektif sehingga motivasi belajarnya tergantung bagaimana anak menerima pola asuh yang diberikan orang tuanya. Dengan pola asuh yang diberikan orang tua akan membuat anak termotivasi dalam melakukan berbagai hal, salah satunya kegiatan membaca. Ketika kegiatan membaca telah ditanamkan sejak dini dan kemudian menjadi kebiasaan dari seorang anak, hal itu tidak hanya bermanfaat terhadap kondisi anak pada saat itu saja, namun juga bermanfaat bagi kehidupan anak di masa depan. Oleh karena itu, anak harus diajarkan bagaimana agar mencintai buku sejak dini.

Pola asuh orang tua merupakan interaksi antara anak dan orang tua selama mengadakan kegiatan pengasuhan. Pengasuhan ini berarti orang tua mendidik, membimbing, dan mendisiplinkan, serta melindungi anak untuk mencapai kedewasaan sesuai dengan normanorma yang ada dalam masyarakat. Orang tua harus dapat memberikan pola asuh yang tepat sesuai dengan perkembangan anaknya, agar anak dapat menerima pola asuh yang diberikan kepadanya dengan baik sehingga dapat memotivasi kegiatan membacanya. Pola asuh orang tua adalah sikap orang tua dalam membimbing anaknya.

Ada juga sebagian orang tua membiarkan anak-anaknya bermain-main tanpa batasan waktu atau dapat pula dikarenakan orang tua terlalu sibuk bekerja sehingga tidak ada waktu untuk memperhatikan pendidikan anak, bahkan ada anak yang dipaksakan harus bekerja membantu orang tuanya seperti berjualan dikarenakan tuntutan ekonomi, sehingga tidak ada waktu lagi 
untuk belajar. Adanya kecenderungan pola asuh orang tua yang kurang jelas, tingkat minat baca anak pun menurun. Dari kondisi di atas maka dapat dilihat adanya kesenjangan antara pola asuh orang tua dengan motivasi membaca anak. Dimana pola asuh orang tua merupakan faktor yang sangat penting dalam minat baca anak, karena semakin diperhatikan oleh orang tua maka anak akan semakin termotivasi dalam membaca.

Melalui penelitian ini diharapkan ada hasil yang bisa dijadikan masukan bagi para orang tua agar bisa mengetahui betapa pentingnya memberikan pola asuh yang tepat terhadap anak sehingga dengan pola asuh yang diberikan tersebut akan membuat anak semakin termotivasi dalam membaca. Mengingat pentingnya peran orang tua dalam menumbuhkan minat baca anak, maka peneliti tertarik untuk mengungkap adakah hubungan antara pola asuh orang tua dengan minat baca anak. Adapun tujuan dari penelitian ini adalah:

1. Untuk mengetahui seberapa besar hubungan kehangatan orang tua dengan minat baca anak.

2. Untuk mengetahui seberapa besar hubungan kontrol orang tua dengan minat baca anak.

\section{TINJAUAN PUSTAKA}

Membaca adalah proses berpikir yang sangat mengandalkan cara kerja (gerakan) mata dan cara kerja otak. Membaca bisa mempertajam pikiran, anjuran itu berlaku untuk semua jenis bacaan, bahkan komik anak-anak sekali pun. Membaca, bukan merupakan faktor keturunan, tetapi harus dididik dan dilatih sejak dini. Di sinilah sebetulnya peran keluarga yang sangat besar yaitu membiasakan anak-anak untuk membaca, berbicara, menulis dengan bimbingan orang tua.

Orang tua merupakan bagian dari keluarga dan keluarga adalah lingkungan yang pertama kali ditemui oleh seorang anak. Dalam keluarga, anak belajar bertingkah laku, tumbuh dan berkembang. Pola asuh yang diterima seorang anak bersifat subjektif sehingga motivasi belajarnya tergantung bagaimana anak menerima pola asuh yang diberikan orang tuanya. Dengan pola asuh yang diberikan orang tua akan membuat anak termotivasi dalam melakukan berbagai hal, salah satunya kegiatan membaca. Ketika kegiatan membaca telah ditanamkan sejak dini dan kemudian menjadi kebiasaan dari seorang anak, hal itu tidak hanya bermanfaat terhadap kondisi anak pada saat itu saja, namun juga bermanfaat bagi kehidupan anak di masa depan. Oleh karena itu, anak harus diajarkan bagaimana agar mencintai buku sejak dini.

\section{METODE PENELITIAN}

Metode yang digunakan dalam penelitian ini adalah metode survey dengan format eksplanasi. Penelitian survei adalah penelitian yang dilakukan pada populasi besar maupun kecil, tetapi data yang dipelajari adalah data dari sampel yang diambil dari populasi tersebut, untuk menemukan kejadian-kejadian relative, distribusi, dan hu- bungan-hubungan antar variabel sosiologis maupun psikologis. Penelitian survei adalah penelitian kuantitatif. Dalam penelitian 
survei menggunakan kuesioner sebagai alat pengumpulan data yang pokok. Peneliti menanyakan ke beberapa responden tentang keyakinan, pendapat, karakteristik suatu obyek dan perilaku yang telah lalu atau sekarang (Sugiyono, 2013).

Explanatory survey adalah untuk memperhatikan mengenai kasus-kasus yang terjadi pada situasi dan kondisi tertentu masa kini di dalam masyarakat, dan penjelasannya dengan melakukan survei analisis yang di rancang untuk menjawab pertanyaan yang berbentuk mengapa (Ruslan, 2010). Berkaitan dengan hal tersebut, maka hipotesis yang dapat diajukan yakni, (1) $\mathrm{H}_{0}$

: Tidak ada hubungan antara pola asuh orang tua dengan minat baca anak dan (2) $\mathrm{H}_{1}$ : Terdapat hubungan antara pola asuh orang tua dengan minat baca anak.

\section{HASIL DAN PEMBAHASAN}

Populasi dalam penelitian ini adalah murid di SMP Al Ma'soem yang berjumlah 800 siswa. Sampel adalah bagian kecil yang mewakili kelompok atau keseluruhan yang lebih besar. Teknik pengambilan sampel yang digunakan adalah teknik simple random sampling. Simple random sampling termasuk ke dalam probability sampling yaitu teknik pengambilan sampel yang memberikan peluang yang sama bagi setiap unsur (anggota) populasi untuk dipilih menjadi anggota sampel. Simple random sampling adalah teknik pengambilan anggota sampel dari populasi dilakukan secara acak tanpa memperhatikan strata yang ada dalam populasi itu (Sugiyono, 2013).
Dalam penarikan sampel maka jumlahnya harus representative untuk nanti hasilnya bisa digeneralisasikan. Untuk memenuhi persyaratan tersebut maka dalam penentuan jumlah sampel penulis menggunakan rumus perhitungan Taro Yamane. Kemudian jumlah sampel akan ditentukan dengan jumlah populasi responden atau murid di SMP Al Ma'soem yang berjumlah 800 siswa.

Orang tua adalah pendidik atas dasar hubungan darah, fungsi dan peran orang tua adalah sebagai pelindung setiap anggota keluarga, orang tua merupakan kepala keluarga. Kepribadian seseorang terbentuk sebagai hasil perpaduan antara warisan sifat-sifat, bakat orang tua dan lingkungan di mana ia berada berkembang. Lingkungan pertama yang mulamula memberikan pengaruh yang mendalam adalah keluarga sendiri.

Hasil pendidikan yang dicapai anak selalu dihubung-hubungkan dengan status pendidikan orangtuanya dan sejak lahir pun anak membawa bakat, kesanggupan (potensi) untuk dikembangkan, dan sifat bawaan tertentu. Pembawaan itu akan berkembang sendiri. William Stern mengemukakan mengenai hal tesebut yaitu dalam hukum konvergensi yang mengatakan bahwa hasil perkembangan suatu individu adalah perpaduan (konvergensi) dari faktor-faktor bilogis dengan melalui atau lingkungan. Kedua pengaruh itu dimisalkan dengan dua buah garis yang bertemu (bergabung) pada suatu tempat, kemudian menjadi satu garis yang kuat (Zulkifli, 2006). 
Hasil penelitian yang didapat berdasarkan data yang telah dianalisis sebagai berikut: Pertama, berdasarkan data responden terungkap bahwa lebih dari setengahnya responden berjenis kelamin laki-laki dengan usia responden 11-16 tahun. Kedua, Mengenai data hasil penelitian untuk sub variabel X1 yaitu aspek kehangatan pada pola asuh orangtua lebih dari setengah responden mendapatkan kehangatan yang tinggi dari orang tua. Sub variabel X2 yaitu aspek kontrol pada pola asuh orang tua hampir setengah responden mendapatkan kontrol yang tinggi dari orang tua. Pada variabel Minat Baca Anak hampir setengah dari responden memiliki minat baca yang tinggi.

Ketiga, Untuk mengetahui hubungan antar sub variabel satu dengan sub variabel yang lain, penulis menggunakan korelasi Rank Spearman. Hasil perhitungan dapat dilihat sebagai berikut:

Tabel 1. Hasil Perhitungan

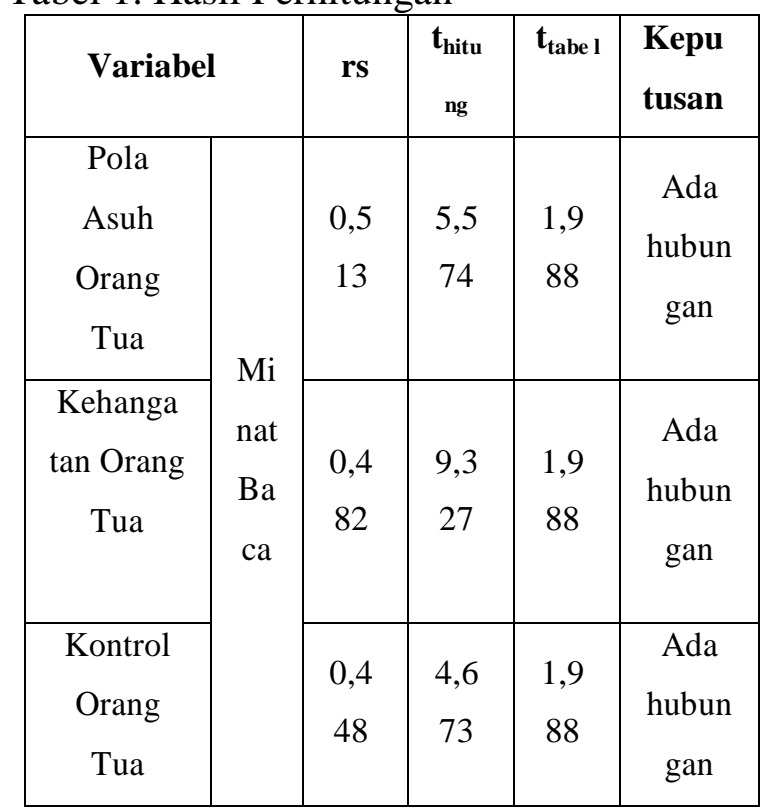

Sumber: Hasil Pengolahan Data

(1) Sesuai dengan hasil penghitungan korelasional yang kemudian dilanjutkan dengan penghitungan uji hipotesis bahwa, diperoleh nilai ${ }^{t}$ hitung $=5,574$ dengan nilai ${ }^{\mathrm{t}}$ tabel $=1,988$. Terlihat bahwa nilai thitung lebih besar daripada nilai yang diperoleh tabel (5,574 $\geq 1,988)$. Didapatkan rs (korelasional) sebesar 0,513. Bila disesuaikan dengan skala Guilford, adalah memiliki hubungan yang sedang. Dengan demikian dapat disimpulkan bahwa terdapat hubungan antara pola asuh orang tua dengan minat baca anak di SMP AL-Ma'soem, Sumedang. Adapun hubungan antara pola asuh orang tua dengan minat baca anak tersebut dapat dikategorikan moderate correlation; substantial relationship.

(2) Sesuai dengan hasil penghitungan korelasional yang kemudian dilanjutkan dengan penghitungan uji hipotesis bahwa, diperoleh nilai ${ }^{t}$ hitung $=9,327$ dengan nilai ${ }^{t}$ tabel $=1,988$. Terlihat bahwa nilai thitung lebih besar daripada nilai yang diperoleh tabel $(9,327 \geq 1,988)$ Didapatkan rs (korelasional) sebesar 0,482. Bila disesuaikan dengan skala Guilford, adalah memiliki hubungan yang sedang. Dengan demikian dapat disimpulkan bahwa terdapat hubungan antara sub variabel kehangatan orang tua dengan minat baca anak di SMP ALMa'soem, Sumedang. Adapun hubungan antara sub variabel kehangatan orang tua dengan minat baca anak tersebut dapat dikategorikan moderate correlation; substantial rela- tionship.

(3) Sesuai dengan hasil penghitungan korelasional yang kemudian dilanjutkan dengan penghitungan uji hipotesis bahwa, diperoleh nilai ${ }^{\mathrm{t}}$ hitung $=4,673$ dengan nilai ${ }^{\mathrm{t}}$ tabel $=1,988$. Terlihat bahwa nilai thitung lebih besar daripada nilai yang diperoleh ${ }^{t}$ tabel $(4,673 \geq 1,988)$ 
Didapatkan rs (korelasional) sebesar 0,448. Bila disesuaikan dengan skala Guilford, adalah memiliki hubungan yang sedang. Dengan demikian dapat disimpulkan bahwa terdapat hubungan yang antara sub variabel kontrol orang tua dengan minat baca anak di SMP ALMa'soem, Sumedang. Adapun hubungan antara sub variabel kontrol orang tua dengan minat baca anak tersebut dapat dikategorikan moderate correlation; substantial relationship.

\section{SIMPULAN}

1) Dari data yang ada terdapat hubungan antara sub variabel parental responsiveness dengan minat baca anak, hubungan yang dimiliki sedang (moderate correlation; substan- tial relationship)

2) Dari data yang ada terdapat hubungan antara sub variabel parental demandingness (kontrol) dengan minat baca anak, hubungan yang dimiliki sedang (moderate correlation; substantial relationship)

3) Sebaiknya para orang tua mulai menerapkan pola pengasuhan yang memiliki tingkat kontrol dan tingkat kehangatan yang tinggi karena akan mempengaruhi minat baca anak menjadi tinggi dan merujuk pada hukum konvergensi William Sterm terdapat satu faktor lagi yang akan mempengaruhi minat baca anak yaitu faktor lingkungan.

\section{DAFTAR PUSTAKA}

Ninivaggi, F. J. (2013). Biomental Child Development: Perspectives on Psychology and Parenting. United States of America: Rowman \& Littlefield Publishers, Inc.
Rahayu, Linda. (2009). Meningkatkan Minat Baca Pada Anak Malang. Malang: UMM.

Rahim, Farida. (2008). Pengajaran Membaca Di Sekolah Dasar. Jakarta: Bumi Aksara.

Ruslan, Rosady. (2010). Metode Penelitian Public Relations Dan Komunikasi. V. Jakarta: RajaGrafindo Persada.

Sugiyono. (2013). Metode Penelitian Kuantitatif, Kualitatif, Dan Kombinasi (Mixed Method). Bandung: Penerbit Alfabeta.

Tarigan, Henry Guntur. (2011). Membaca Ekspresif. Edisi Revi. Bandung: Percetakan ANGKASA.

Yusuf, S. (2010). Psikologi Perkembangan Anak Dan Remaja. Bandung: Remaja Rosdakarya.

Zulkifli L, Drs. 2006. Psikologi Perkembangan. Edited by Tjun and Pakar Dady Surjaman. Keenam. Bandung: PT Remaja Rosdakarya.

El-Fikri, Syahruddin. (2015, $26 \quad$ Mei). Menumbuhkan Minat Baca Masyarakat.

Republika (online). Tersedia: http://www.republika.co.id (13 Januari 2016, 19:40)

Darling, Nancy. (2014, 6 Februari). Parenting Style and Its Correlates. Athealth.

Tersedia: http://athealth.com/topics/parenting-styleand-its-correlates-2/ (13 Januari 2016, 19:50). 
